\title{
FUNGUS BALL IN HIV-INFECTED PATIENTS
}

\section{SUMMARY}

Aspergillus is a phagocyte opportunistic fungus that causes aspergillosis, an unusual disease in patients with AIDS. Six cases of fungal ball in patients with AIDS are reported here. In this group, all patients had hemoptysis and tuberculosis as the underlying lung disease. The diagnosis of pulmonary fungus ball was based on the clinical and radiographic feature, combined with serological and mycological evidence of Aspergillus fumigatus.

KEYWORDS: Aspergillus fumigatus; Fungus ball; AIDS; Tuberculosis; Mycetoma; Aspergilloma.

\section{INTRODUCTION}

Pulmonary aspergillosis has various presentations depending largely on the immune competence of the patient, the type of exposure, and the presence of an underlying disease. Aspergillus fumigatus is the predominant species cultured from the respiratory tract that can cause acute angioinvasive pulmonary aspergillosis and other chronic forms of infection. These entities include chronic necrotizing aspergillosis (semi-invasive), allergic bronchopulmonary aspergillosis, intracavitary colonization (fungus ball), bronchocentric granulomatosis or hypersensitivity pneumonitis. The distinction among subacute, acute angioinvasive pulmonary aspergillosis, chronic necrotizing aspergillosis and fungus ball has not been rigorously defined and an overlap in clinical and radiological features among these different entities probably exist ${ }^{3,10,16,20}$. As Aspergillus is a phagocyte opportunistic fungus, aspergillosis is unusual in patients with AIDS, except in late stages of the viral disease ${ }^{14}$. Fungus ball caused by A. fumigatus is a noninvasive form of pulmonary disease that results from a lung fungal colonization. The empty, post-treatment tuberculosis cavity is the main predisposing factor for fungal colonization in most patients and hemoptysis is the only serious complication ${ }^{17,22}$.

Fungus ball may be divided into simple or complex. While the first one occurs in a cavity without surrounding parenchymal disease, the other occurs in a thick-walled cavity with surrounding parenchymal inflammation and is associated with higher morbidity and mortality ${ }^{2,7}$.

The diagnosis of pulmonary aspergillosis is based on clinical, radiological, and mycological data.

On radiographs, pulmonary fungus ball appears as a solid rounded mass of unique density, sometimes mobile, within a spherical or ovoid cavity, and separated from the wall of the cavity by airspace of variable size and shape ${ }^{21,25}$. Chest tomography (CT) demonstrates excellent advantage from chest radiograph for the intracavitary colonization diagnostic, showing the presence of a mass in a pre-existing cavity while this fungus ball is not yet apparent on radiography $y^{3,11,16,26}$.

The most consistent diagnostic features of fungus ball are hemoptysis, chronic cough, usually productive, and an upper-lobe, mobile intracavitary mass with an air crescent in the periphery seen on the chest radiograph. Precipitating antibodies to species of Aspergillus (radial immunodiffusion) in the patients serum are found in virtually all patients, it has $>95 \%$ sensitivity for fungus ball, except in HIV-infected patients ${ }^{9,22,23}$. But a definitive diagnosis is established by microscopical demonstration of the septate hyphae and conidiophore of Aspergillus and/or culturing the Aspergillus from percutaneous aspirate/biopsy, fiberoptic bronchoscopy and resected specimens of the cavity ${ }^{19}$. Sometimes the cultures from material taken from surgical specimens are negative because of non-viable organisms within the fungal mass and/or secondary bacterial colonization ${ }^{9}$. Besides those, there are nonculture-based microbiological methods to facilitate rapid diagnosis and to monitor infection progression and response to therapy. Promising methods include antigen-based assays (serology), metabolite detection, and molecular detection of fungal DNA from body fluid samples ${ }^{3,10}$.

Pulmonary aspergillosis is rarely found in HIV positive patients, mainly in comparison with its prevalence in other risk group as patients with conditions that produce a similar degree of immunosuppression, such as organ transplantation, lymphoma and leukemia ${ }^{11,13}$. Pulmonary fungus ball in HIV-infected patient differs in several features from those in the immunocompetents. HIV positive patients are particularly susceptible to cavitary lung disease, including pneumatoceles secondary to Pneumocystis jirovecii pneumonia and tuberculosis, as well as

(1) Post-Graduation Program in Pneumologic Science, Universidade Federal do Rio Grande do Sul (UFRGS).

(2) Laboratory of Mycology, Hospital Santa Rita, Santa Casa-Complexo Hospitalar, Porto Alegre, RS, Brazil

(3) Hospital Sanatório Partenon, Secretaria da Saúde e do Meio Ambiente, RS.

(4) Department of Mycology, Universidade Federal do Rio Grande (FURG).

(5) Department of Internal Medicine, UFRGS, Porto Alegre, RS, Brazil.

(6) Researcher 1B from CNPq.

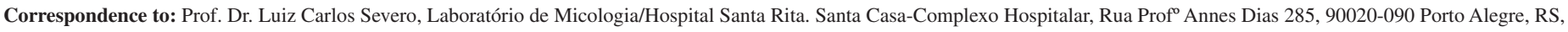

Brasil. Phone: +55.51.32148409; Fax: +55.51.32148435. E-mail: severo@ santacasa.tche.br, severo@ pesquisador.cnpq.br 
necrotizing bacterial pneumonias. These patients are less likely to significant hemoptysis.

Treatment has to be individualized, depending on the severity of the symptoms, extent and location of the pulmonary involvement, relationship to other diseases, and the patient's general condition. Thus, treatment of fungal ball must be adapted specifically to each patient, with the entire clinical presentation dictating the appropriate management. Treatment with a combination of antiretroviral and antifungal therapy appears to be effective in improving the clinical and radiographic outcomes of patients with HIV infection and pulmonary fungus ball ${ }^{6,8,21}$.

In our study all patients presented a solid round mass, which was located in a single spherical, or ovoid cavity, therefore we termed it as fungus ball. Medical records were reviewed years after diagnosis of fungus ball, we considered that those patients didn't outcome to chronic necrotizing aspergillosis or invasive disease. The rarity in those reports of pulmonary fungus ball in patients with AIDS indicates the importance of describing this series of six cases.

\section{MATERIAL AND METHODS}

In order to identify cases of possible fungus ball in HIV infected individuals, we retrospectively reviewed 485 cases of fungus ball diagnosed in the Mycology Laboratory (Santa Casa - Complexo Hospitalar, Porto Alegre, RS, Brazil), from 1980 to 2008. Charts, chest radiographs, CT scans, data from mycology cultures, serum immunodiffusion, bronchoscopic and surgical specimens, HIV testing, viral loads, and CD4 levels were evaluated. Patients were included if they: (1) had a suggestive chest radiograph of fungus ball and evidence from culture, serum radial immunodiffusion (ID), pathologic specimen with Aspergillus spp., or if they had CT scan evidence of fungus ball and (2) were HIV-infected based on a positive enzyme-linked immunosorbent assay result that was confirmed by Western blot. Patients were excluded if charts and/or radiographs could not be obtained, if they were HIV-negative as determined by enzyme-linked immunosorbent assay, or if no HIV test had been performed.

Clinical presentation was evaluated in each case. When follow-up was available, the patients' subsequent treatment, symptoms, radiographs, laboratory results, and clinical findings were recorded. Disease progression or improvement was defined radiographically (change in size of fungus ball cavity and/or surrounding infiltrate) or clinically (change in symptoms of cough and/or hemoptysis).

\section{RESULTS}

The patients' ages ranged from 26 to 50 years old, all of them had fungus ball in the upper lobes of the lungs and had tuberculosis as the underlying disease. The main symptoms were cough and hemoptysis that were classified as blood-streaked sputum, mild-to-moderate (< $100 \mathrm{~mL} / 24 \mathrm{~h}$ ). Four patients had hepatitis C. Fungal ball diagnostic was made by ID, direct mycological examination and culture of the respiratory tract samples. A. fumigatus was the etiologic agent of all cases (Table 1). The case 2 of this series in CT revealed multiple fungus balls (Fig.1 and 2).

Table 1

Cases descriptions of six HIV positive patients with fungus ball

\begin{tabular}{|c|c|c|c|c|c|c|c|c|}
\hline $\begin{array}{l}\text { Patient No/ } \\
\text { Age/Sex }\end{array}$ & $\begin{array}{l}\text { CD4 } \\
\text { Count } \\
(\text { Cells } / \mu \mathrm{L})\end{array}$ & $\begin{array}{l}\text { Associated/ } \\
\text { predisposing } \\
\text { disease }\end{array}$ & $\begin{array}{l}\text { Clinical } \\
\text { signs }\end{array}$ & $\begin{array}{l}\text { Fungus ball } \\
\text { localization }\end{array}$ & $\begin{array}{l}\text { Diagnostic } \\
\text { test of } \\
\text { aspergillosis }\end{array}$ & HAART & Treatment & Outcome \\
\hline $1 / 28 / \mathrm{M}$ & 566 & $\begin{array}{l}\text { TB, } \\
\text { Hepatitis C, } \\
\text { Hepatitis B. }\end{array}$ & $\begin{array}{l}\text { Hemoptysis, } \\
\text { cough, dyspnea, } \\
\text { fever, } \\
\text { chest pain. }\end{array}$ & LUL & $\begin{array}{l}\mathrm{ID}(+) \\
\operatorname{SpCult}(+)\end{array}$ & Yes & $\begin{array}{l}\text { Itraconazole } \\
\text { Embolization, } \\
\text { Radiotherapy }\end{array}$ & $\begin{array}{l}\text { No change (10 } \\
\text { months) }\end{array}$ \\
\hline $2 / 26 / \mathrm{M}$ & 161 & $\begin{array}{l}\text { TB, } \\
\text { Hepatitis C. }\end{array}$ & Hemoptysis. & $\begin{array}{l}\text { LUL and } \\
\text { RLL }\end{array}$ & $\begin{array}{l}\mathrm{ID}(+) \\
\text { Sp DM(+) } \\
\text { Cult(+) }\end{array}$ & Yes & Itraconazole & $\begin{array}{l}\text { No change } \\
\text { (48 months) }\end{array}$ \\
\hline $3 / 42 / \mathrm{M}$ & 138 & $\begin{array}{l}\text { TB, } \\
\text { Hepatitis C, } \\
\text { CMV, } \\
\text { adrenal failure. }\end{array}$ & $\begin{array}{l}\text { Hemoptysis, } \\
\text { cough, dyspnea. }\end{array}$ & RUL & $\begin{array}{l}\mathrm{ID}(+) \\
\operatorname{Sp~DM}(+) \\
\text { Cult(+) }\end{array}$ & Yes & Lobectomy & $\begin{array}{l}\text { No } \\
\text { Follow-up }\end{array}$ \\
\hline $4 / 50 / \mathrm{M}$ & 540 & $\begin{array}{l}\text { TB, } \\
\text { Hepatitis C. }\end{array}$ & $\begin{array}{l}\text { Hemoptysis, } \\
\text { cough, dyspnea. }\end{array}$ & $\begin{array}{l}\text { LUL and } \\
\text { RUL }\end{array}$ & $\begin{array}{l}\mathrm{ID}(+) \\
\operatorname{Sp~DM}(+) \\
\text { Cult(+) }\end{array}$ & Yes & Itraconazole & $\begin{array}{l}\text { No } \\
\text { Follow-up }\end{array}$ \\
\hline $5 / 31 / \mathrm{M}$ & Not done & TB & $\begin{array}{l}\text { Hemoptysis, } \\
\text { cough, } \\
\text { fever. }\end{array}$ & LUL & $\begin{array}{l}\operatorname{ID}(+) \\
\operatorname{TBBX}(+)\end{array}$ & No & Pleuropneumectomy & $\begin{array}{l}\text { No } \\
\text { Follow-up }\end{array}$ \\
\hline $6 / 34 / \mathrm{F}$ & Not done & TB & $\begin{array}{l}\text { Hemoptysis, } \\
\text { cough. }\end{array}$ & RUL & $\mathrm{ID}(+)$ & No & Itraconazole & $\begin{array}{l}\text { Symptomatic } \\
\text { Improvement } \\
\text { (48 months) }\end{array}$ \\
\hline
\end{tabular}

Age and CD4 count at first presentation. TB: Tuberculosis; HAART: Highly active antiretroviral therapy; LUL: left upper lobe; RUL: right upper lobe; RLL: right lower lobe; Sp: sputum; TBBX: transbronchial biopsy; ID: immunodifusion for A. fumigatus; Cult: Culture; DM: Direct microscopy; F: Female; M: Male; CMV: cytomegalovirus. 


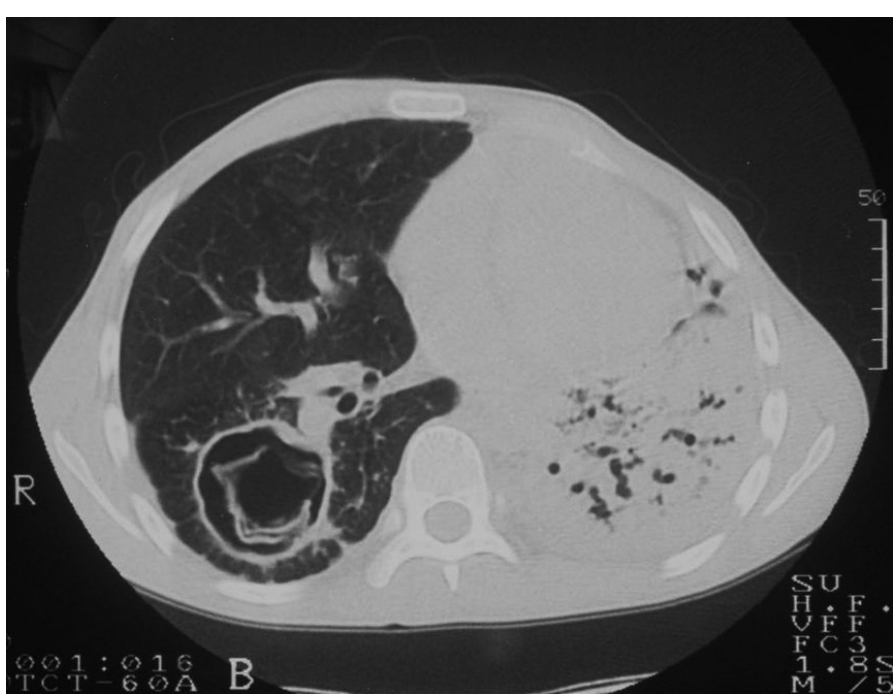

Fig.1 - Spherical cavity $(5 \mathrm{~cm})$ within laminar pathological material localized in inferior right lobe.

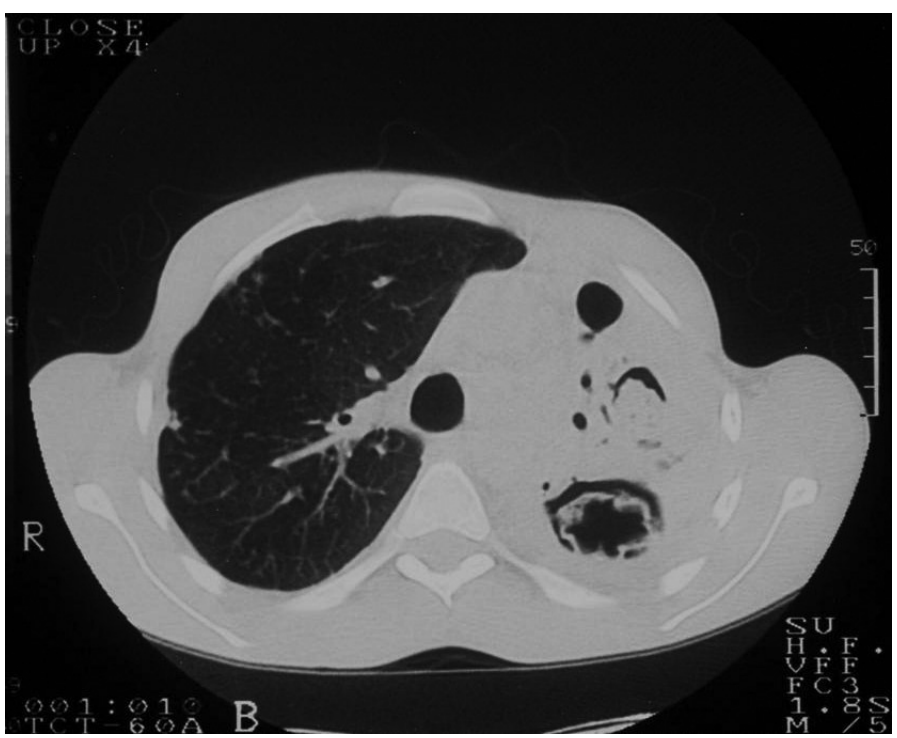

Fig. 2 - Left pulmonary parenchyma destruction with two cavities in the superior third Upper cavity ( $3 \mathrm{~cm}$ diameter) within spherical mass, and cavity below $(4 \mathrm{~cm})$ within laminar pathological material.

Illustrative Case (Case 1): A 28-year-old male, presenting fever, dyspnea, chest pain, cough and hemoptysis for two months was admitted to the hospital. The patient had a chronic hepatopathy due to $\mathrm{B}$ and $\mathrm{C}$ hepatitis virus and had received an incomplete treatment for tuberculosis two years before when he had positive sputum smear for acid-fast bacilli and HIV test (enzyme-linked immunosorbent assay confirmed by Western blot). At the time of presentation his sputum was negative for staining of acid-fast bacilli but he was started on tuberculosis therapy because of previous incomplete treatment with zidovudina (AZT), didanosina (DDI) and sulfamethoxazol-trimetroprim (SMT-TMP).

Physical examination revealed a febrile and undernourished patient with digital clubbing. Wheezing and rales were noted in both lungs. A roentgenogram of the chest disclosed a total destruction of the left lung.
The left upper lobe had a cavity containing a soft tissue mass (fungus ball). A. fumigatus was recovered in culture (performed in Sabouraud dextrose agar with chloramphenicol at $25{ }^{\circ} \mathrm{C}$ ) and A. fumigatus ID was positive. Itraconazole ( $200 \mathrm{mg} /$ day) was started, and at this moment his CD4 was 566 cells $/ \mu \mathrm{L}$. Seven months later he had another episode of hemoptysis so arterial embolization was made, followed by radiotherapy two months later. With ten months of treatment, the culture of the sputum on Sabouraud dextrose agar still revealed A. fumigatus and there was no radiological change. It was indicated the continuity of treatment with itraconazole outpatient.

\section{DISCUSSION}

Fungus ball in immunocompetent patients is well documented in the literature. However, few cases of this aspergillosis presentation in patients with AIDS were reported ${ }^{8,10}$.

Fungus ball had been described predominantly as a consequence of preexisting tuberculosis cavities, but other diseases are also implicated as precursors of this entity although less often. Some of them are related to immunodepression ${ }^{5}$. A previous study comparing HIV-infected and HIV-negative individuals found pneumocystosis as a predisposing factor in HIV-infected individuals as a risk factor for fungus ball ${ }^{1}$. In addition, another series of 20 cases describing fungus ball in HIV-infected patients also found eight cases of pneumocystosis as a predisposing factor ${ }^{7}$. This implication was not confirmed in our study, because no HIV patients with fungus ball had $P$. jirovecii infection associated.

The presentation and clinical course of pulmonary fungus ball in the HIV-infected patient differs in several ways from those in the immunocompetent patient ${ }^{17}$. HIV positive patients are particularly susceptible to cavitary lung disease, including pneumatoceles secondary to $P$. jirovecii pneumonia and tuberculosis, as well as necrotizing bacterial pneumonias $^{1,8}$.

All HIV patients included in the present study had moderate hemoptysis. In fact, these patients are less likely to have significant hemoptysis, which is much more common among the HIV-negative individual, $73 \%$ compared with $40 \%$ of HIV-infected individuals. On the other hand, they have a high risk of disease progression, including the development of possible semi-invasive illness ${ }^{1,8}$. Patients with fungus ball generally have one to four arcs of precipitation antibodies (immunodiffusion test). The absence of precipitating antibody in a small number of patients may be related to the presence of dead fungi, deficiency of gamma globulin, immunosuppressive therapy, or poor antigenicity of the pathogenic fungi ${ }^{14,24}$. Although our patients were immunosuppressed by HIV infection, their immunodiffusion characteristics were similar to immunocompetent patients, even those with low CD4 count, without false negative results.

Surgery procedures are indicated in symptomatic patients due to the high risk of massive and fatal hemoptysis. Resection surgery is the treatment of choice for localized disease, simple fungus ball, in suitable candidates. Two patients of the present study were included in this group. Resection should only be undertaken if there is sufficient respiratory reserve and the resection removes minimal functioning pulmonary tissue $^{1,8,11,23}$. Itraconazole, used as treatment in four of our patients, can be considered as the first choice in the therapy of fungus ball due to its 
lipophilic characteristic, which results in a great concentration of the drug in the cavity of fungus balls $\mathrm{s}^{26,28}$. Bronchial artery embolization, procedure also used in the illustrative case, although temporarily effective, has been used to occlude the vessel that supplies the bleeding site in patients experiencing hemoptysis. Additional treatments for hemoptysis have included radiotherapy $7,18,20,23$.

Given the fact that this was a retrospective study, there are some limitations as to monitoring and evaluation of treatment. However, tuberculosis seems to be the main risk factor to fungus ball in this study despite HIV status, or $\mathrm{CD}_{4}$ count. Thus, we alert clinicians to the importance of a constant and rigorous monitoring of the treatment and the evolution of HIV patients with tuberculosis, endemic disease in Brazil.

\section{RESUMO}

\section{Bola fúngica em pacientes HIV-infectados}

Os fungos filamentosos são oportunistas de fagócitos, motivo pelo qual aspergilose é incomum em pacientes com Aids. A apresentação clínica depende do estado imune, tamanho do inóculo fúngico e doença de base. São relatados neste trabalho seis casos de bola fúngica em pacientes com Aids. Neste grupo, todos tiveram tuberculose como doença de base e hemoptise foi o principal sintoma. O diagnóstico da bola fúngica foi através da apresentação clínica, achados radiológicos combinados com imunodifusão radial dupla, exame micológico direto e cultivo do material do trato respiratório, sendo A. fumigatus o agente isolado.

\section{REFERENCES}

1. ADDRIZZO-HARRIS, D.J.; HARKIN, T.J.; McGUINNESS, G.; NAIDICH, D.P. \& ROM, W.N. - Pulmonary aspergilloma and AIDS. A comparison of HIV-infected and HIV-negative individuals. Chest, 111: 612-618, 1997.

2. BELCHER, J.R. \& PLUMMER, N.S. - Surgery in broncho-pulmonary aspergillosis.Brit. J. Dis. Chest, 54: 335-341, 1960.

3. DENNING, D.W.; FOLLANSBEE, S.E.; SCOLARO, M. et al. - Pulmonary aspergillosis in the acquired immunodeficiency syndrome. New Engl. J. Med., 324: 654-662, 1991.

4. DENNING, D.W.; RINIOTIS, K.; DOBRASHIAN, R. \& SAMBATAKOU, H. - Chronic cavitary and fibrosing pulmonary and pleural aspergillosis: case series, proposed nomenclature change, and review. Clin. infect. Dis., 37(suppl. 3): S265-S280, 2003.

5. FALKSON, C.; SUR, R. \& PACELLA, J. - External beam radiotherapy: a treatment option for massive haemoptysis caused by mycetoma. Clin. Oncol., 14: 233-235, 2002.

6. GREENBERG, A.K.; KNAPP, J.; ROM, W.N. \& ADDRIZZO-HARRIS, D.J. - Clinical presentation of pulmonary mycetoma in HIV-infected patients. Chest, 122: 886-892, 2002.

7. HENDERSON, R.D.; DESLAURIER, J.; RITCEY, E.L.; DELAURE, N.C. \& PEARSON, F.G. - Surgery in pulmonary aspergillosis. J. thorac. cardiovasc. Surg., 70: 10881094, 1975.

8. HÖHLER, T.; SCHNÜTGEN, M.; MAYET, W.J. \& MEYER ZUM BUSCHENFELDE K.H. - Pulmonary aspergilloma in a patient with AIDS. Thorax, 50: 312-313, 1995.
9. JEWKES, J.; KAY, P.H.; PANETH, M. \& CITRON, K.M. - Pulmonary aspergilloma: analysis of prognosis in relation to haemoptysis and survey of treatment. Thorax, 38: $572-578,1983$

10. JUDSON, M.A. - Noninvasive Aspergillus pulmonary disease. Semin. Resp. crit. care Med., 25: 203-219, 2004

11. KEATING, J.J.; ROGERS, T.; PETROU, M. et al. - Management of pulmonary aspergillosis in AIDS: an emerging clinical problem. J. clin. Path., 47: 805- 809, 1994.

12. KURUP, V.P. \& KUMAR, A. - Immunodiagnosis of aspergillosis. Clin. Microbiol. Rev., 4: 439-456, 1991.

13. MHAWECH, P.; KRISHNAN, B. \& SHAHAB, I. - Primary pulmonary mucosa-associated lymphoid tissue lymphoma with associated fungal ball in a patient with human immunodeficiency virus infection. Arch. Path. Lab. Med., 124: 1506-1509, 2000.

14. MYLONAKIS, E.; BARLAM, T.F.; FLANIGAN, T. \& RICH, J.D. - Pulmonary aspergillosis and invasive disease in AIDS: review of 342 cases. Chest,114: 251-262, 1998.

15. NASH, G.; IRVINE, R.; KERSCHMANN, R. \& HERNDIER, B. - Pulmonary aspergillosis in acquired immune deficiency syndrome: autopsy study of an emerging pulmonary complication of human immunodeficiency virus infection. Hum. Path., 28: 1268$1275,1997$.

16. RICHARD, L.; KRADIN, M.D.; EUGENE, J. \& MARK, M.D. - The pathology of pulmonary disorders due to Aspergillus spp. Arch. Path. Lab. Med., 132: 606-614, 2008

17. SEVERO, L.C.; GEYER, G.R. \& PORTO, N.S. - Pulmonary Aspergillus intracavitary colonization (PAIC). Mycopathologia, 112: 93-104, 1990.

18. SHNEERSON, J.M.; EMERSON, P.A. \& PHILLIPS, R.H. - Radiotherapy for massive haemoptysis from an aspergilloma. Thorax, 35: 953-954, 1980.

19. SMITH, R.L.; MORELLI, M.J. \& ARANDA, C.P. - Pulmonary aspergilloma diagnosed by fiberoptic bronchoscopy. Chest, 92: 948-949, 1987.

20. SOUBANI, A.O. \& CHANDRASEKAR, P.H. - The clinical spectrum of pulmonary aspergillosis. Chest, 121: 1988-1999, 2002.

21. STEVENS, D.A.; KAN, V.L.; JUDSON, M.A. et al. - Practice guidelines for diseases caused by Aspergillus. Clin. infect. Dis., 30: 696-709, 2000.

22. TOMEE, J.; VAN DER WERF, T.; LATGE, J. et al. - Serologic monitoring of disease and treatment in a patient with pulmonary aspergilloma. Amer. J. respir. crit. care Med., 151: 199-204, 1995.

23. TOMEE, J.F. \& VAN DER WERF, T.S. - Pulmonary aspergillosis. Neth. J. Med., 59: $244-258,2001$

24. TSUBURA, E. - Multicenter clinical trial of itraconazole in the treatment of pulmonary aspergilloma. Kekkaku., 72: 557-564, 1997.

25. WALSH, T.J.; ANAISSIE, E.J.; DENNING, D.W. et al. - Infectious Diseases Society of America. Treatment of aspergillosis: clinical practice guidelines of the Infectious Diseases Society of America. Clin. infect. Dis., 46: 327-360, 2008.

26. ZMEILI, O.S. \& SOUBANI, A.O. - Pulmonary aspergillosis: a clinical update. Q. J. Med., 100: 317-334, 2007.

Received: 6 April 2009

Accepted: 3 November 2009 